\title{
Social Representations of Economic Crisis in Italian and Greek Social Groups*
}

\author{
Ida Galli \\ University of Naples \\ "Federico II", \\ Naples, Italy
}

\author{
Maria Geka \\ Aristotle University \\ ofThessaloniki, \\ Thessaloniki, Greece
}

\author{
Anna Liguori \\ University of Geneva, \\ Geneva, Suisse
}

\author{
Roberto Fasanelli \\ University of Naples \\ "Federico II", \\ Naples, Italy
}

The aim of this study is to investigate how culture and expertise of a complex phenomenon, the economic crisis, influence the construction of different social representations. In order to analyse the "naif theories" elaborated by the common sense with regard to the economic thinking and acting, this research has been conducted inside the theoretical framework of SRT (Social Representation Theory). By interviewing Italian and Greek subjects belonging to different social groups, we examined how "expert" and "lay" people face this unfamiliar phenomenon. Inspired by the Structural Approach, which considers SRs (social representations) as constituted of two parts, a structure and a content, data were collected through a multi-method strategy (hierarchized evocations method, characterization and multiple choice questionnaires). Four groups of participants ( $n=120$ for each country; $n=30$ for each group; gender balanced) were employed: university students (the second/third year; faculty of economics), mid-level bank clerks, shopkeepers, and laypeople. Obtained data were treated with rang/frequency and similarity analysis, as well as mono and multivariate statistical analysis. Discussion focuses on the relationships between culture, group appurtenance and social representations of crisis and economic behaviors. The main findings demonstrate culture and group appurtenance differences in the ways participants define and foresee strategies to face the crisis. In particular, in both Italian and Greek samples, differences were founded among expert and lay groups. Methodological implications associated with combining qualitative and quantitative methods, in SRT's Structural Approach, are systematically presented and discussed.

Keywords: social representations, central nucleus theory, network analysis, lay knowledge, economic crisis, Italy, Greece, social groups.

\section{Introduction}

Social actors operate under "a basic imperative to construct explanations for the events that surround them". However, an individual cannot look into the world and directly perceive a macro-economic process. The only way to "know" the issue is through the mediation of other people or institutions, including experts, media outlets and conversational partners. Understanding how lay explanation of economic phenomena develops

\footnotetext{
*Acknowledgments: The authors acknowledge professor Pierre Vergès for his helpful scientific suggestions.

Ida Galli, Department of Social Sciences, University of Naples "Federico II".

Maria Geka, School of Psychology, Aristotle University ofThessaloniki.

Anna Liguori, Department of Psychology,University of Geneva.

Roberto Fasanelli, Department of Social Sciences, University of Naples "Federico II".
} 
therefore "requires a theoretical framework in which the constitutive role of social context and communication processes is central" (O'Connor, 2012, pp. 453-455).

Social representations "offer a sophisticated understanding of economic phenomena's impact on social masses" because the TSR (theory of social representations) "contributes to our understanding of the societal process of sense making, when an unfamiliar external shock comes down on society" (Puashunder, 2012, p.15). The main function of every social representations is to make familiar the unfamiliar, usual the unusual (Moscovici, 1984b) and granting orientation in times of change (Moscovici, 1984a).

Thus, a formerly unfamiliar phenomenon, the economic crisis, with its attributed features and meanings, becomes part of the social world of a social group and coordinates its actions. Unknown and unexpected social phenomena often fuel discussions among citizens about the unknown and stimulate a search for information needed in order to understand the new phenomenon, communicate successfully and develop strategies to cope with it. Media reports, discussions, and debates in society serve the purpose of familiarizing the public with the unknown and developing shared representations of the phenomena (Rouquette, 1996; Wagner et al., 1999 as cited in Gangl, Kastlunger, Kirchler, \& Voracek, 2012, p. 604). Through capturing discourse and knowledge-exchange in the social compound, social representations thereby allow for a delineating dynamic process of socio-economic adaptation (Kirchler, 2007). According to Vergès (1994a), a plurality of discourses exists in the economic field, whose validation is essentially of a social order: "Nous désignons par représentations économiques les représentations sociales d'un domaine particulier: celui que la société dénomme économique" (p. 387). The objective of the study of social representations in the area of economics has to be "how ordinary people perceive an economic phenomenon" (Vergès, Tyszka, \& Vergès, 1994; p. 25). Assuming that what is transmitted is always a set of notions given by economists and that the main vehicle of economic knowledge is everyday personal experience, on the one hand, and media communication, on the other, it becomes interesting to understand if ordinary people use those notions, in the same meaning and relations, or work out their particular way of conceived economics.

This research is part of a wider international study realized starting from 2009 in different European countries (France, Great Britain, Greece, Italy and Romania) among the activities of CeMeRS (the "Mediterranean Center for the study of Social Representaions"). Data related to the first phase of the research (beginning period of the crisis) were already published in a special issue of the Cahiers Internationaux de Psychologie Sociale (Galli, Markova, Bouriche, Fasanelli, Geka, Jacob, \& Jacob, 2010).

The purpose of this investigation is to examine the structure and the content of different social groups' representations and their relation with social practices in two different countries: Italy and Greece. The study has been articulated in the following research questions: "Do different social groups construct different social representations of the economic objects? What are the differences among the SR of an economic crisis produced in different cultural contexts?"

The first objective concerns how the social representation of the economic crisis developed within different social groups. This link between different social representations and different social groups is something that characterizes the TSR development. It regards not only different ways to access to information that different social groups have (Jodelet, 1984; 1989), but also the whole articulation of the SR. Pierre Vergès (1994a) underlines that economic representations depend on the social structuring of their themes. Different social groups don't articulate economic or non-economic elements in the same way, because social actors 
establish very specific economic/non-economic articulations, according to the different social practices and different signification universes they take part in. Also Tyszka (2001) expresses this concept, focusing on the direct experience that different social groups have and which "forms not only descriptive aspects of our economic representation but also our evaluations and attitudes toward objects" (p. 171). Works about the link between social practices and correspondent social representation (Guimelli, 1989), undeniably, let us suppose that to be part of a professional group which can activate particular social representations (Mardellat, 1994). It can also determine ways of judgements and memorization in relation with the central core of these groups' social representations (Michit, 1994a). Michit (1994b) has given empirical evidence to the fact that different professional groups - bankers and social workers - can differently react to a given situation, in selecting, judging and memorizing information. Differences in activating social representations can depend not only on the professional environment, but also on the socio-economic and cultural context. Vergès (1994a) explicates the cultural fundament of an economic representation by saying that "as social productions, economic representations keep their content from different sites of determination: practice, ideology, and cultural memory of social groups" (p. 446). Tyszka (2001), for his part, referring to empirical evidence from cross-cultural research, specifies that a social representation "may be different for individuals and groups living in specific socio-economic environments. Divergent experience of the economic world should lead to different cognitive representations of economics" (p. 171).

Cultural differences are what we want to investigate as our second purpose of research: We aim to understand if differences between social representations of economic crisis stand between social groups from different cultural contexts. Many cross-cultural researches have already tried to show these kinds of differences, relating to social representations of economic objects (Dehm \& Muller-Peters, 2001; Meier \& Kirchler, 1998). A cross-cultural research, carried out in six countries, on the social representations of economics among students, showed: (1) that students from different countries do not consider business and society as completely distinct worlds, but as interconnected by the action of socio-economic individuals; and (2) that students have different points of view on economy, related to the social and economic condition of each country of origin (Vergès \& Bastounis, 2001; Zappalà, 2001; Vergès et al., 1994). Tyszka (2001), trying to shed light upon the influence of mass media communication versus influence of different socio-economic and cultural contexts on social representations of economics, examines two cross-cultural studies. The first one, part of wider research cited by Zappalà (2001), which is focused on the perception of economic activities between French and Polish students (Vergès et al., 1994) shows a difference in perception of consumption and household economy. The second, about the perception of economic activities among full-time employees (Antonides, Farago, Ranyard, \& Tyszka, 1997), tried to test the differences between social representations of economics in a state controlled vs. marked oriented countries. These differences concern the way to evaluate socio-economical activities. As Legardez (2004) synthesizes, Vergès defines three levels of social determinations. A cultural matrix of interpretation (the first level) which comprehends, on one side, elements of national culture (i.e., the global representation of economics) is centered differently depending on the individual's nationality in a strongly stable way (Vergès, Albertini, \& Legardez, 1995); on the other side, it comprehends some elements characteristic of the social group they belong to. The social representations of State role in economics could be different when it comes to the function of the milieu social of individuals. Social practices (the second level) such as professional, monetary, consumption activities, and so on. The discourses circulate in a determined 
moment in the society (the third level). These discourses come from the media, social organizations, influential people and more largely by all members of a society and can be considered as opinion discourses: Everybody could have on the weight of a specialist in economics inside a society.

\section{Materials and Method}

Agreeing with the Verges and Bastounis (2001) position about studying an SR of an economic object, "it therefore becomes necessary to take on complementary instruments and forms of analysis, able to provide an organized description of the data. Such complementary data would expand the information obtained illustrating the relationships that bind the concepts" (p. 35). In the direction also indicated by Moscovici (1989, as cited in de Rosa, 1994) on the utilization of a multi-method approach (de Rosa, 1990; Galli, 2003, 2006), this study is articulated in three different phases that utilize: a "descriptive approach", to find out the structure and the content of the SR for every social group in each country; an "interpretative approach", to understand the social situation in which positions, judgments and behaviours of the involved subjects take place; a "comparative approach", to underline differences among representations worked out in different cultural contests.

The chosen non-probabilistic sample was composed of 120 subjects for each country, equally distributed in four social categories:

(1) university students (the second/third year; faculty of economics);

(2) bank clerks (medium level);

(3) shopkeepers;

(4) lay people.

The participants have been balanced not only on each category $(n=30)$, but also on gender (15 F-15 M). They also had to be in a defined range of age (30-60 years old), and from the same geographic area.

Strategies adopted to contact interviewees have been diversified on the typology of each groups: Students were reached at university, during their break were between courses; bank clerks were contacted and interviewed making appointments at their work place and choosing people from agencies in relation to their collaboration or geographical proximity; shopkeepers were interviewed on appointment and at their work place too; lay people were contacted in the street, next to/inside shops.

Studying a social representation, in the structural approach (Abric, 1994a, 2003; Flament, 1994a, 1994b; Guimelli, 1994; Vergès, 1994a, 1994b, 1995), means, first of all, to find out the constitutional elements of the structure.

Identical contents can correspond to a totally different symbolic universe and, consequently, imply dissimilar social representations (Galli, 2003; Fasanelli, Galli, \& Sommella, 2005). As Zappalà (2001) suggests, "The theory of central and peripheral systems allows one to compare groups or countries, disclosing the structuring principles of a specific economic object and the network of associations which give them sense" (pp. 200-201).

In this theoretical framework, to reach the "significant elements" of the social representation of an economic crisis, and to reconstruct the organization of these elements, it has chosen to use the Method of Hierarchized Evocation (Vergès, 1992; Abric \& Vergès, 1994; Vergès \& Bastounis, 2001; Abric, 2003). In the first part of the interview, after an open question about the social definition of the "crisis", the participants were asked to answer to a free associations and consequent hierachization task, as Vergès' method provides (Vergès 
1992; Vergès \& Bastounis, 2001). The former request is to express the first five terms they think from the inductor term ("economic crisis" in our case) and the latter is to order them, by expressing the level of importance the interviewees give to each one. The association/hierarchy task is proposed to the participants by asking not only the first nouns but also, separately, the first five adjectives they thought of from the given inductor, to better understand the elements of the SR both in their normative/descriptive aspects (Moliner, 1995). Besides, the free association task was completed by open questions about the subjective justification linked to every associated term, with the aim to avoid lexical ambiguity, which is typical of this kind of data (Fasanelli et al., 2005). The answers to these questions were useful in order to understand, through the given explanation, the meaning of every term associated with it and it was important for the semantic analysis of free evocations as well as to reach a specific representational process. The whole method of evocation wants to satisfy the necessity to achieve the three different cognitive processes, that characterize the evolution of every social representation (Vergès, 1992): (1) the selection process (when social actors select the organizing principles of the social representation) which coincides with free association/hierachization tasks; (2) the connotative process (when social actors judge and qualify the selected elements) corresponds to the request of the five adjectives, i.e., attributes; and (3) the schematization process (when social actors enlighten how these elements have been put together) fits in the open answers. A QCha (Questionnaire of Characterization) was added to check the hypothesis of centrality of the elements identified by using the previous method (Vergès, 2001). It gives a kind of information which: "met en évidence la nature de l'item dans ses rapports avec l'objet représenté : dans quelle mesure un item fait partie du Noyau central d'une représentation. Pour en faire partie, il doit à la fois être partagé par tous, c'est-à-dire fréquent, et organisateur de la représentation, donc essentiel pour chacun" (Vergès, 1995). The QCha was realized starting from social descriptions and explanations of the crisis, identified in the previous study (Galli et al., 2010). The participants were asked to order the first most important five statements and the first least important statements, among a list of 15 (according to the rule of a multiple of 3 ) to code every item with a score of 1 (less characteristic), 3 (more characteristic), or 2 (not chosen).

Only the combination of the two described methods can give the possibility of making a more complete hypotheses on the nature of the central core: "les réponses aux seuls questionnaires de caractérisation ne permettent que de formuler des hypothèses sur la centralité des éléments (comme l'utilisation des seules réponses aux évocations hiérarchisées)" (Abric, 2003, p. 69). Consequently, it seems necessary to use both of them to better understand the results: "la concordance concernant le noyau cntral obtenu par au moins deux outils différents étant une première garantie de la réalité de l'existence et de la nature de ce noyau" (Abric, 2003, p. 69).

Vergès (1994a) states that with the interview we could be able on one side, to reach this structure and, on the other, to show how this structure can be translated in argumentation. For that reason, to access the content of the social representation of the economic crisis, a series of QCho (Questionnaires of Choice) were constructed, starting from the results of the content analysis of the answers given to a previous set of open questions, made up by an intercultural équipe (Galli et al., 2010). This section of the questionnaire investigated the following dimensions: cognitive-evaluative aspects about the structure of the representation (central and peripheral elements); descriptive-defining aspects of the representation; informative sources and interaction networks; level of involvement/implication and distance from the object; relationship between representation 
and social practices; perceptions and categorizations (causes, responsibilities, duration/evolution, solutions, positive implications, the EU's role).

The terms evocated by the participants were firstly treated with a lexical and categorical analysis. In the lexical phase, they were aggregated on the basis of the synonymy criterion in order to obtain clusters of terms substantially coincidental with the manifest meaning (Bardin, 2003). We chose to analyze the "content" and not the "discourse" because, according to Vergès (1994a), the focus of this analysis has to be not limited to the argumentative form of the answers. On the contrary, one has to understand their content and their sense, in the conviction that the analysis of the form of social actors discourse, though natural logic, can and must be associated with the analysis of the SRs' content determinations. Therefore, using a semantic criterion, terms have been further aggregated starting from their justifications. Each of the obtained cluster was associated with a new label. Every label was identified using, as a selective criteria, the high semantic proximity and frequency of occurrence of every term aggregated inside of it. The obtained data were finally processed by the software Evoc2005. The hierarchized evocation analysis was allowed to reach the elements, which constitute the central core and the periphery of the social representation of the economic crisis, for each group of participants. The output of this analysis appears as a "double entry" table, where elements can be interpreted from the position they have in the four cells. Specifically, the first one (the upper left cell, high frequency and rank) groups the most frequent and important elements, which delimit the central nucleus area. In the second cell (upper right, high frequency and low rank), there are the most important peripheral elements (the "first periphery" of the nucleus), which give useful information to better reconstruct the social practices related to the SR object. In the third one (the lower left cell, low frequency, high rank), there are the contrast/complementary (to central) elements, that could configure a nucleus of an SR shared by a minority of group members. The last cell (the lower right, low frequency and low rank) coincides with the area of the "second periphery", constituted by the elements less present and less important in the structural organization investigated. In this paper, only data from substantives' free association will be presented.

Similarity analysis (Flament, 1962; Vergès \& Bouriche, 2009) was supported by the software Simi2005, with the advantage to better show the organizational structure of the significant elements of every SR. This analysis consists of an elaborate matrix of similarity starting from the selected index, which depends on the nature of the relationship among the considered variables. In our case, the co-occurrences index was used for hierarchized evocated terms and QCho data and Kendall's tau for chosen for QCha data. The graphic output of this analysis consists of a graph, where the significant elements of the SR are shown with different kinds of links (more or less marked), on the basis of their value and selected threshold, which express the relations (and their strength) between structural elements and their network. The final graphs were elaborated using the logic of the thresholds graph, rather than the arbre maximum, in order to serve the best number of information about the clustering elements (Vergès \& Bouriche, 2009).

Data from the questionnaire of characterization were explored using a descriptive analysis and a similarity analysis, both to confirm/not confirm the hypothesis of centrality of the elements intended to be in the nucleus.

Data from QCho were investigated using a similarity analysis, not only in a traditional way, but furthermore in a multidimensional procedure, which consists of analysing together more components of the social representation. In particular, strategies and changes registered in social practices, attributions and 
solutions, were involved in this reassessment of a multidimensional similarity analysis realized by Abric and Vergès (1994) in their study on the social representation of the bank.

Moreover, a descriptive analysis (SPSS supported) was conducted on all the variables to verify the presence of differences among the groups of participants (Chi-square test).

Table 1

Central Cores. Italian/Greek Whole Sample

\begin{tabular}{lll}
\hline & Italian whole sample & Greek whole sample \\
\hline Hierarchized evocations central core & Job loss & Job loss \\
& Incapacity of politics & Anguish \\
Characterization central elements & Increase of poverty & Insecurity \\
& Job loss & Job loss \\
& & Salaries decrease \\
\hline
\end{tabular}

Table 2

Central Cores. Italian/Greek Subsamples

\begin{tabular}{|c|c|c|c|c|}
\hline Italian subsamples & Students & Bank clerks & Shopkeepers & Lay people \\
\hline \multirow[t]{2}{*}{\begin{tabular}{|l|} 
Hierarchized \\
evocations central core
\end{tabular}} & Job loss & Job loss & Job loss & Job loss \\
\hline & & & Uncertainty, fear of future & \\
\hline \multirow{2}{*}{$\begin{array}{l}\text { Characterization } \\
\text { central elements }\end{array}$} & Job loss & Job loss & Job loss & Job loss \\
\hline & Uncertainty, fear of future & Uncertainty, fear of future & Slump of consumptions & Uncertainty, fear of future \\
\hline Greek subsamples & Students & Bank clerks & Shopkeepers & Lay people \\
\hline \begin{tabular}{|l|} 
Hierarchized \\
evocations central core
\end{tabular} & Job loss & Job loss & Job loss & \begin{tabular}{|ll}
$\begin{array}{l}\text { Indigence, } \\
\text { starvation }\end{array}$ & misery, \\
\end{tabular} \\
\hline \multirow{4}{*}{$\begin{array}{l}\text { Characterization } \\
\text { central elements }\end{array}$} & & Job loss & & Job loss \\
\hline & Uncertainty, fear of future & Uncertainty, fear of future & Uncertainty, fear of future & Uncertainty, fear of future \\
\hline & Salaries decrease & & Salaries decrease & Salaries decrease \\
\hline & Prices increase & Generalized distrust & Stress and frustration & \\
\hline
\end{tabular}

Table 3

SREC Structure. Greek Student's Substantives

\begin{tabular}{|c|c|c|c|c|c|c|}
\hline & \multicolumn{6}{|c|}{ Importance } \\
\hline & \multicolumn{3}{|c|}{$<2.5$} & \multicolumn{3}{|c|}{$\geq 2.5$} \\
\hline \multirow{10}{*}{ Frequency } & Job loss & 20 & 2.25 & Debt & 8 & 2.62 \\
\hline & & & & Increase of poverty & 12 & 3.00 \\
\hline & & & & Austerity measures & 8 & 3.62 \\
\hline & FMI & 6 & 2.16 & Less money to spend & 6 & 3.33 \\
\hline & Anguish & 4 & 2.25 & Immigration & 3 & 4.00 \\
\hline & Incapacity of politicians & 3 & 1.00 & Banks & 3 & 3.00 \\
\hline & Politics & 3 & 2.33 & Uncertainty of future & 4 & 3.75 \\
\hline & Salaries decrease & 4 & 2.25 & Deficit & 3 & 2.66 \\
\hline & & & & Inflation & 3 & 3.00 \\
\hline & & & & Indigence, misery, starvation & 4 & 3.25 \\
\hline
\end{tabular}


Table 4

SREC Structure. Greek Bank Clerks’ Substantives

\begin{tabular}{|c|c|c|c|c|c|c|}
\hline & \multicolumn{6}{|c|}{ Importance } \\
\hline & \multicolumn{3}{|c|}{$<2.5$} & \multicolumn{3}{|c|}{$\geq 2.5$} \\
\hline \multirow{14}{*}{$\begin{aligned} \text { Frequency } & \\
& <8\end{aligned}$} & Job loss & 14 & 2.28 & Increase of poverty & 9 & 2.77 \\
\hline & & & & Uncertainty of future & 8 & 3.25 \\
\hline & Anguish & 3 & 2.33 & Less money to spend & 3 & 4.33 \\
\hline & Insecurity & 5 & 2.40 & Anger & 3 & 2.66 \\
\hline & Indignant & 2 & 2.00 & Decadency & 3 & 2.66 \\
\hline & Limits & 2 & 2.00 & Indigence, misery, starvation & 5 & 3.20 \\
\hline & Recession & 2 & 1.00 & Depression & 2 & 4.50 \\
\hline & & & & Debt & 2 & 2.50 \\
\hline & & & & Euro & 2 & 3.00 \\
\hline & & & & Incapacity of politics & 2 & 5.00 \\
\hline & & & & Infelicity & 2 & 3.00 \\
\hline & & & & Fear & 2 & 4.00 \\
\hline & & & & Loans & 2 & 3.00 \\
\hline & & & & Earnings & 2 & 2.50 \\
\hline
\end{tabular}

Table 5

SREC structure. Greek Shopkeepers' Substantives

\begin{tabular}{|c|c|c|c|c|c|c|}
\hline & \multicolumn{6}{|c|}{ Importance } \\
\hline & \multicolumn{3}{|c|}{$<2.5$} & \multicolumn{3}{|c|}{$\geq 2.5$} \\
\hline & Job loss & 17 & 2.00 & Increase of poverty & 6 & 3.00 \\
\hline$\geq 6$ & & & & Indigence, misery, starvation & 8 & 3.00 \\
\hline & & & & Decadency & 6 & 2.50 \\
\hline & Anguish & 4 & 1.75 & Taxes & 2 & 3.00 \\
\hline & FMI & 2 & 1.50 & Failure & 2 & 3.50 \\
\hline & & & & Uncertainty of future & 2 & 3.00 \\
\hline \multirow[t]{2}{*}{ Frequency } & & & & Insecurity & 3 & 2.66 \\
\hline & & & & Reduction & 2 & 3.00 \\
\hline \multirow[t]{5}{*}{$<6$} & & & & Exploitation & 2 & 3.50 \\
\hline & & & & Salaries decrease & 2 & 4.00 \\
\hline & & & & Rebellion & 2 & 3.50 \\
\hline & & & & Robbery & 2 & 3.50 \\
\hline & & & & Incapacity of politicians & 3 & 3.00 \\
\hline
\end{tabular}

Table 6

SREC Structure. Greek Laypeople's Substantives

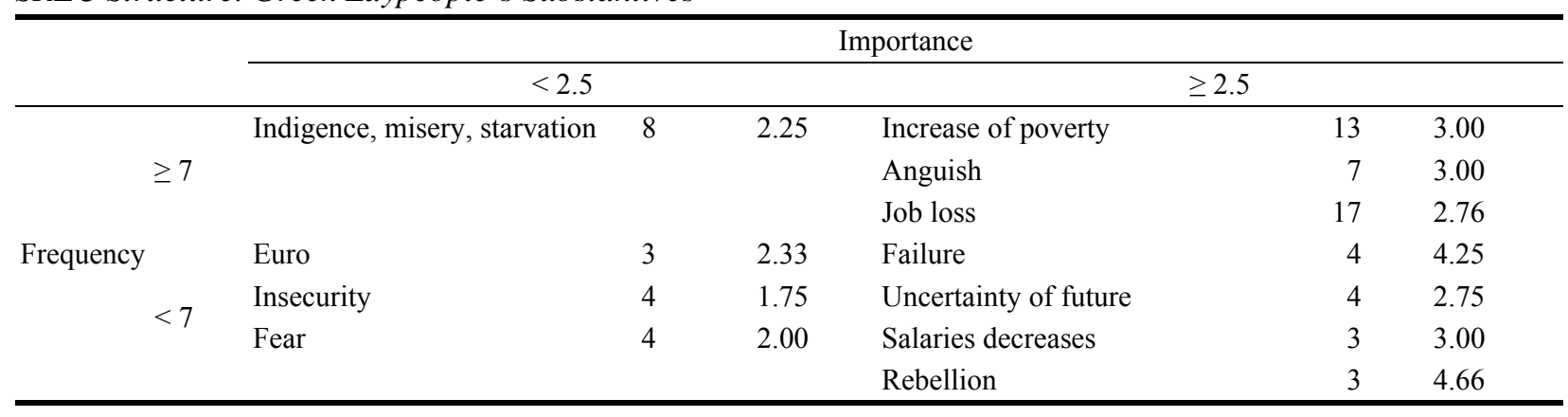


Table 7

SREC Structure. Italian Students' Substantives

\begin{tabular}{|c|c|c|c|c|c|c|c|}
\hline & & \multicolumn{6}{|c|}{ Importance } \\
\hline & & \multicolumn{3}{|c|}{$<2.5$} & \multicolumn{3}{|c|}{$\geq 2.5$} \\
\hline \multirow{12}{*}{ frequency } & \multirow{4}{*}{$\geq 11$} & Job loss & 21 & 2.19 & High cost of living & 13 & 3.30 \\
\hline & & & & & Uncertainty/fear of future & 11 & 2.30 \\
\hline & & & & & Less money to spend & 15 & 3.80 \\
\hline & & & & & Ref. to economy & 11 & 3.00 \\
\hline & \multirow{8}{*}{$>11$} & Increase of poverty & 5 & 2.00 & Bank at the origin & 8 & 2.87 \\
\hline & & Incapacity of politics & 9 & 1.77 & Bank effect & 4 & 4.00 \\
\hline & & Taxes & 5 & 2.60 & Causes & 7 & 3.28 \\
\hline & & Victims & 4 & 2.50 & Crisis enterprises & 4 & 3.75 \\
\hline & & & & & Ref. to finance & 6 & 3.00 \\
\hline & & & & & Distrust & 8 & 4.12 \\
\hline & & & & & Hope in possible solutions & 3 & 3.00 \\
\hline & & & & & Social tension & 2 & 3.50 \\
\hline
\end{tabular}

Table 8

SREC Structure. Italian Bank Clerks’ Substantives

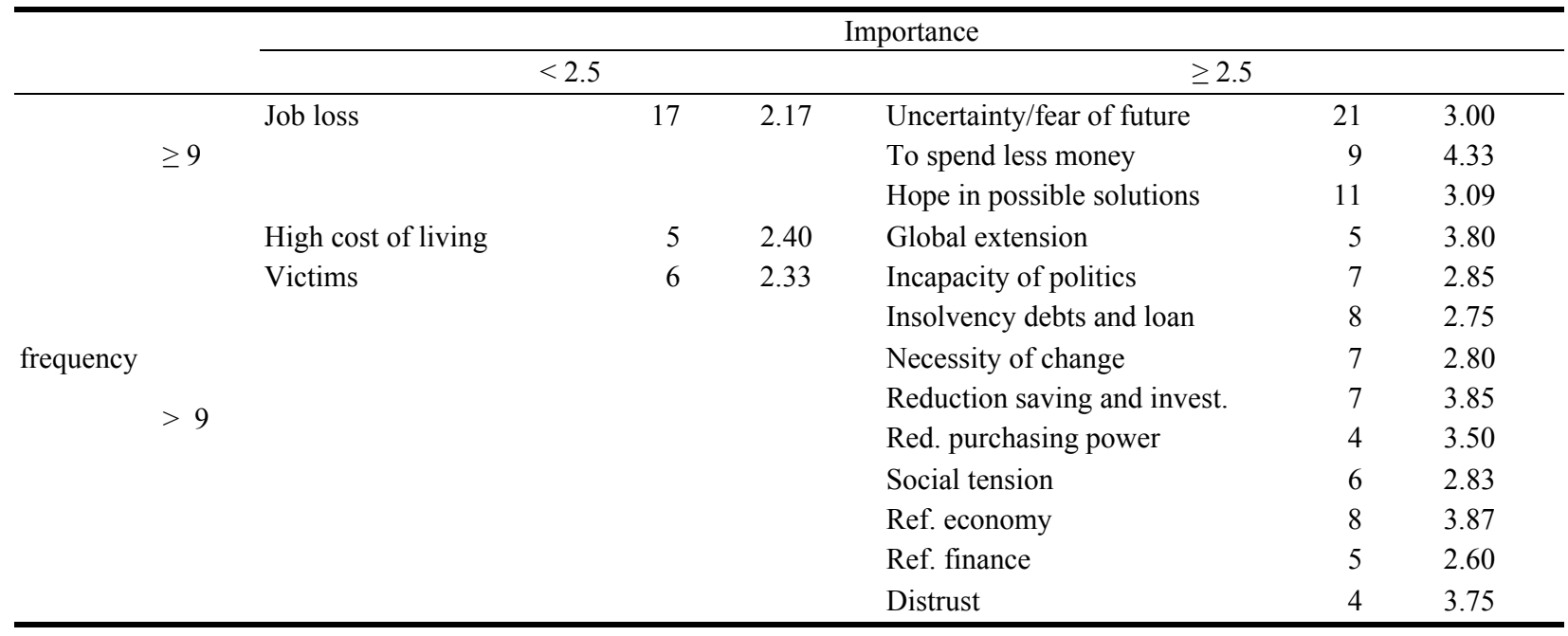

Table 9

SREC Structure. Italian Shopkeepers' Substantives

\begin{tabular}{|c|c|c|c|c|c|c|c|}
\hline & & \multicolumn{6}{|l|}{ Importance } \\
\hline & & $<2.5$ & & & $\geq 2.5$ & & \\
\hline \multirow{11}{*}{ frequency } & \multirow{4}{*}{$\geq 11$} & Job loss & 13 & 2.15 & High cost of living & 15 & 3.20 \\
\hline & & \multirow[t]{3}{*}{ Uncertainty./fear of future } & \multirow[t]{3}{*}{14} & \multirow[t]{3}{*}{2.42} & Less money to spend & 22 & 3.27 \\
\hline & & & & & Neg. exp. and feelings & 13 & 3.00 \\
\hline & & & & & Incapacity of politics & 11 & 2.63 \\
\hline & & \multirow[t]{7}{*}{ Increase of poverty } & \multirow[t]{7}{*}{8} & \multirow[t]{7}{*}{2.37} & Euro & 4 & 3.00 \\
\hline & \multirow{6}{*}{$<11$} & & & & Ref. to finance/economy & 3 & 3.00 \\
\hline & & & & & Poor culture & 3 & 3.66 \\
\hline & & & & & Possible solution & 8 & 3.37 \\
\hline & & & & & Spec. enterprises & 5 & 3.20 \\
\hline & & & & & Taxes & 9 & 2.88 \\
\hline & & & & & Victims & 6 & 3.33 \\
\hline
\end{tabular}


Table 10

SREC Structure. Italian Laypeople's Substantives

\begin{tabular}{|c|c|c|c|c|c|c|c|}
\hline & & \multicolumn{6}{|c|}{ Importance } \\
\hline & & \multicolumn{3}{|c|}{$<2.5$} & \multicolumn{3}{|c|}{$\geq 2.5$} \\
\hline \multirow{11}{*}{ frequency } & \multirow{5}{*}{$\geq 11$} & \multirow[t]{5}{*}{ Job loss } & \multirow[t]{5}{*}{20} & \multirow[t]{5}{*}{2.20} & \multirow{2}{*}{$\begin{array}{l}\text { High cost of living } \\
\text { Uncertainty/fear future }\end{array}$} & 10 & 3.60 \\
\hline & & & & & & 22 & 2.68 \\
\hline & & & & & \multirow{2}{*}{$\begin{array}{l}\text { Less money to spend } \\
\text { Incapacity of politics }\end{array}$} & 14 & 4.00 \\
\hline & & & & & & 13 & 3.00 \\
\hline & & & & & Ref. to economy & 11 & 3.81 \\
\hline & \multirow{6}{*}{$>11$} & Possible solutions & 9 & 2.55 & Increase of poverty & 7 & 3.00 \\
\hline & & Neg. exp. and feelings & 9 & 2.33 & \multirow{2}{*}{$\begin{array}{l}\text { Aggravation quality of life } \\
\text { Ref. finance }\end{array}$} & 5 & 2.80 \\
\hline & & & & & & 4 & 2.75 \\
\hline & & & & & Role Europe & 4 & 3.50 \\
\hline & & & & & Causes & 5 & 3.20 \\
\hline & & & & & Taxes & 3 & 3.33 \\
\hline
\end{tabular}

Table 11

Characterization Data (Percentages of Choice): Greek Students

\begin{tabular}{lcll}
\hline Items & Least characteristic & Not selected & Most characteristic \\
\hline Uncertainty, fear of future & 0 & 20 & 80 \\
Salaries decrease & 0 & 17 & 83 \\
Prices increase & 17 & 23 & 60 \\
Job loss & 0 & 40 & 60 \\
Slump of consumptions and sales & 10 & 77 & 13 \\
Savings and investments reduction & 13 & 73 & 13 \\
Malfunctioning of banks and finance & 10 & 63 & 27 \\
Stress and frustration & 30 & 40 & 30 \\
Slump of purchasing power & 20 & 57 & 23 \\
Generalized distrust & 30 & 53 & 17 \\
Phase of the economic cycle & 37 & 43 & 20 \\
Demand decrease/ offer excess & 33 & 43 & 23 \\
\hline
\end{tabular}

Table 12

Characterization Data (Percentages of Choice): Greek Bank Clerks

\begin{tabular}{lccc}
\hline Items & Least characteristic & Not selected & Most characteristic \\
\hline Uncertainty, fear of future & 4 & 14 & 82 \\
Job loss & 11 & 18 & 71 \\
Generalized distrust & 21 & 29 & 50 \\
Stress and frustration & 18 & 32 & 50 \\
Salaries decrease & 4 & 36 & 61 \\
Malfunctioning of banks and finance & 21 & 36 & 43 \\
Demand decrease/ offer excess & 25 & 75 & 0 \\
Savings and investments reduction & 11 & 75 & 14 \\
Slump of purchasing power & 7 & 75 & 18 \\
Slump of consumptions and sales & 14 & 50 & 36 \\
Prices increase & 46 & 50 & 4 \\
Phase of the economic cycle & 43 & 43 & 14 \\
Something inevitable & 82 & 14 & 4 \\
Media invention & 71 & 14 & 14 \\
Conspiracy, plot & 64 & 14 & 21 \\
\hline
\end{tabular}


Table 13

Characterization Data (Percentages of Choice): Greek Shopkeepers

\begin{tabular}{lccc}
\hline Items & Least characteristic & Not selected & Most characteristic \\
\hline Uncertainty, fear of future & 0 & 4 & 96 \\
Salaries decrease & 0 & 30 & 70 \\
Stress and frustration & 0 & 30 & 70 \\
Job loss & 4 & 37 & 59 \\
Slump of consumptions and sales & 0 & 44 & 56 \\
Savings and investments reduction & 0 & 85 & 15 \\
Demand decrease/ offer excess & 19 & 70 & 11 \\
Slump of purchasing power & 4 & 70 & 26 \\
Malfunctioning of banks and finance & 19 & 59 & 22 \\
Prices increase & 26 & 59 & 15 \\
Generalized distrust & 15 & 56 & 30 \\
Phase of the economic cycle & 48 & 48 & 4 \\
Something inevitable & 63 & 37 & 0 \\
Media invention & 63 & 33 & 4 \\
Conspiracy, plot & 48 & 30 & 22 \\
\hline
\end{tabular}

Table 14

Characterization Data (Percentages of Choice): Greek Laypeople

\begin{tabular}{lcll}
\hline Items & Least characteristic & Not selected & Most characteristic \\
\hline Uncertainty, fear of future & 3 & 14 & 83 \\
Job loss & 0 & 28 & 72 \\
Salaries decrease & 0 & 31 & 69 \\
Demand decrease/ offer excess & 24 & 66 & 10 \\
Savings and investments reduction & 21 & 66 & 14 \\
Phase of the economic cycle & 38 & 59 & 3 \\
Prices increase & 28 & 55 & 17 \\
Malfunctioning of banks and finance & 17 & 45 & 38 \\
Slump of purchasing power & 3 & 59 & 38 \\
Slump of consumptions and sales & 10 & 52 & 38 \\
Stress and frustration & 0 & 52 & 48 \\
Generalized distrust & 17 & 41 & 41 \\
Conspiracy, plot & 41 & 41 & 17 \\
Something inevitable & 62 & 38 & 0 \\
Media invention & 52 & 41 & 7 \\
\hline
\end{tabular}

Table 15

Characterization Data (Percentages of Choice): Italian Students

\begin{tabular}{lcll}
\hline Items & Least characteristic & Not selected & Most characteristic \\
\hline Job loss & 3 & 13 & 83 \\
Prices increase & 13 & 27 & 60 \\
Uncertainty, fear of future & 23 & 23 & 53 \\
Salaries decrease & 7 & 43 & 50 \\
Generalized distrust & 20 & 47 & 33 \\
Slump of consumptions and sales & 3 & 50 & 47 \\
Malfunctioning of banks and finance & 20 & 50 & 30 \\
\hline
\end{tabular}


Table 15 continued

\begin{tabular}{llll}
\hline Items & Least characteristic & Not selected & Most characteristic \\
\hline Slump of purchasing power & 7 & 53 & 40 \\
Savings and investments reduction & 20 & 53 & 27 \\
Demand decrease/offer excess & 30 & 57 & 13 \\
Stress and frustration & 50 & 27 & 23 \\
Phase of the economic cycle & 63 & 20 & 17 \\
Something inevitable & 63 & 30 & 7 \\
Media invention & 83 & 17 & 0 \\
Conspiracy, plot & 87 & 3 & 10 \\
\hline
\end{tabular}

Table 16

Characterization Data (Percentages of Choice): Italian Bank Clerks

\begin{tabular}{llll}
\hline Items & Least characteristic & Not selected & Most characteristic \\
\hline Generalized distrust & 10 & 37 & 53 \\
Uncertainty, fear of future & 3 & 33 & 63 \\
Job loss & 7 & 30 & 63 \\
Prices increase & 20 & 53 & 27 \\
Demand decrease/offer excess & 27 & 50 & 23 \\
Salaries decrease & 3 & 53 & 43 \\
Slump of consumptions and sales & 10 & 43 & 47 \\
Savings and investments reduction & 10 & 50 & 40 \\
Slump of purchasing power & 20 & 37 & 43 \\
Phase of the economic cycle & 40 & 30 & 30 \\
Stress and frustration & 50 & 20 & 30 \\
Malfunctioning of banks and finance & 47 & 37 & 17 \\
Something inevitable & 73 & 17 & 10 \\
Conspiracy, plot & 77 & 17 & 7 \\
Media invention & 90 & 10 & 0 \\
\hline
\end{tabular}

Table 17

Characterization Data (Percentages of Choice): Italian Shopkeepers

\begin{tabular}{lcll}
\hline Items & Least characteristic & Not selected & most characteristic \\
\hline Job loss & 0 & 30 & 70 \\
Slump of consumptions and sales & 7 & 27 & 67 \\
Prices increase & 13 & 27 & 60 \\
Slump of purchasing power & 10 & 40 & 50 \\
Salaries decrease & 7 & 47 & 47 \\
Uncertainty, fear of future & 23 & 40 & 37 \\
Generalized distrust & 37 & 30 & 33 \\
Stress and frustration & 30 & 27 & 43 \\
Malfunctioning of banks and finance & 43 & 23 & 33 \\
Savings and investments reduction & 13 & 53 & 33 \\
Demand decrease/offer excess & 43 & 43 & 13 \\
Something inevitable & 47 & 47 & 7 \\
Phase of the economic cycle & 60 & 33 & 7 \\
Media invention & 77 & 23 & 0 \\
Conspiracy, plot & 87 & 13 & 0 \\
\hline
\end{tabular}


Table 18

Characterization Data (Percentages of Choice): Italian Laypeople

\begin{tabular}{lcll}
\hline Items & Least characteristic & Not selected & Most characteristic \\
\hline Uncertainty, fear of future & 0 & 20 & 80 \\
Generalized distrust & 23 & 33 & 43 \\
Job loss & 3 & 30 & 67 \\
Malfunctioning of banks and finance & 37 & 20 & 43 \\
Stress and frustration & 47 & 20 & 33 \\
Prices increase & 13 & 53 & 33 \\
Demand decrease/offer excess & 33 & 43 & 23 \\
Salaries decrease & 30 & 43 & 27 \\
Slump of consumptions and sales & 7 & 50 & 43 \\
Savings and investments reduction & 0 & 57 & 43 \\
Slump of purchasing power & 13 & 43 & 43 \\
Phase of the economic cycle & 47 & 40 & 13 \\
Media invention & 90 & 10 & 0 \\
Conspiracy, plot & 87 & 10 & 3 \\
Something inevitable & 70 & 27 & 3 \\
\hline
\end{tabular}

\section{Results and Discussion}

If we look at the different central cores of the whole Italian and Greek groups of participants (see Tables 1 and 2), we can notice that both focused on "Job loss", as confirmed by Hierarchized Evocations and by Questionnaire of Characterization. The other common element is "Uncertainty, fear of future", confirmed as central in the characterization results for the Italian SR's structure and even evoked in the Greek one. These last interviewees refer to these feelings calling to mind "Anguish" and "Insecurity" (see Tables 3, 4, 5, and 6): anguish "for what is going to happen in the next future and how we can face it" (StudGR_M1) or "for the next future of all the Greeks for the country in its interior and for the international scene too" (ShopGR_M42) and insecurity as "uncertainty for the day after" (ShopGR_M34) or of "stable work, insecurity of future of sons" (LayGR_F75). In the Italian whole sample central core (see Table 1), there are two elements, the "Increase of poverty and incapacity of politics", that do not appear in the Greek central core, but in the first periphery.

Looking into the differences in the hierarchized evocations, a particular attention among Greek participants is linked to "Decadency" and "Austerity measures" (see Tables 3, 4, 5 and 6), both present in some of the SRsEC structures and both referred to the particular 2012 Greek situation. "Decadency" in fact, is more salient for shopkeepers, that evokes it among the first peripheral terms and refers to the terrible degeneration of the health and education system in Greece. A sort of "social collapse", which is not only expressible as a qualitative degeneration, but in a real limitation of access for common people to health and education services: "Tragic the health services" (ShopGr_F54); "Lack of medicines" (LayIt_F115). Unless the theme of austerity is something that appears in 2012 also in the Italian public debate, "Austerity measures" are evoked only by Greek participants, who are probably suffering more the consequences of that strategy, imposed by UE. In Italy, the expression that more corresponds to austerity is generically "Taxes", a term that has incremented its evocation from 2009 to 2012 in parallel with the perception of its increase. "Taxes" also occurs among the possible solutions, in fact, "Taxes and levies reduction" was chosen (as the first choice in the related section of the questionnaire) by $56.67 \%$ of shopkeepers and $23.33 \%$ of laypeople. Among Italian participants, "Taxes" are 
evoked referring to their inequality and weight, mainly among shopkeepers, but also to their evasion. In particular, among students, taxes are associated to their inevitability: "because they kill us and they are not at all equal" (ShopIt_M21); "despite attempts to counter tax evasion, they will always be many who will try to avoid paying taxes" (LayIt_F20); "to survive taxation increases" (StudIt_F8); "EU measures are geared to a better taxation and a reduction of interest rates" (StudIt_M20). Otherwise "Austerity measures", among Greek participants, assume a different kind of consciousness. In particular, among students, this awareness is testified by the specificity of the references, not generically to "taxes", but more properly to "austerity measures" and, in many cases, even the explicit reference to "mnemonio". The latter reference bears witness to a more technical knowledge about the main vehicle of austerity measures (better known as "memorandum"), in comparison with other Greek sub-samples, but also with Italian students. For these people, "Austerity" measures mean measures, austerity and mnemonio: "There will be hard measures for people and our life" (StudGr_M4); "People live with what is necessary" (StudGr_M27); “A policy that leads nowhere” (StudGr_F29).

Anyway, what testifies the level that crisis has reached for Greek participants is probably the presence of a particular category, "Indigence, misery, starvation", in the first periphery of the whole sample's SR and in the central core of laypeople's SR. This element expresses a dimension of poverty that, among Italian free associations, has just appeared as "High cost of living" (see Tables 7, 8, 9, and 10). So, Italian participants start to live the difficulties of the access to what before was a normal standard of life. In this specific representational dimension, we found references to school, which is "always more expensive" (ShopIt_F15), to alimentation and food that is "the first and last thing to be affected by crisis; "the first one to suffer the cost of living and the last that is possible to afford" (ShopIt_F11). Finally, interviewees refer also to health, because "it's a big problem (to find economical resources) when it comes a health problem" (ShopIt_F12).

To summarize, while for Italian participants these three words, indigence, misery and starvation (see Tables 7, 8, 9, and 10) are evoked just a few time talking about the incumbent poverty, for the Greek participants (see Tables 3, 4, 5 and 6), they are more frequent and express a graver, impellent situation. An extreme dimension of poverty, expressed by their proper meaning: "No money to eat" (StudGr_F24); "We arrive to mercy" (ShopGr_F52); "Lots of people live in starvation and the next ones are us" (ShopGr_F53); "A big part of population has no money, even for necessary things" (LayGr_F114).

Another consideration that emerges comparing Italian and Greek central cores is that in the case of the Greek ones, characterization results (see Tables 11, 12, 13 and 14) do not confirm the centrality of "Job loss" for two groups of participants, students and shopkeepers. For both groups, in fact, characterization analysis evidences the centrality of "Uncertainty, fear of future" and "Salaries decrease", but also of "Prices increase" for students and "Stress and frustration" for shopkeepers. Differently from what happens for Italian participants, in the case of Greek students and shopkeepers, the centrality of "Job loss" is overcome by other elements. Among Italian interviewees, otherwise, "Job loss" is not only spontaneously evoked (see Tables 7, 8, 9 and 10), but also confirmed as central element by the characterization questionnaire, that reveals that it is considered as the most characteristic for over $60 \%$ of every group of participants (see Tables 15, 16, 17 and 18). Its symbolic and expressive value is not negligible together with its associative value: similitude analysis of evoked terms, both in 2009 and 2012, shows its centrality because of the high number of links and in its generally central position.

Besides in Greek data, there aren't so big differences among groups of participants. It seems to prevail the consideration of "what crisis is not" rather than "what crisis is", as it happens for Italian laypeople. In comparison with Italian results, Greek representations seem to be more coherent with the empirical evidences 
of Vergès et al. (1994), who underlined how basic cognitive representations of economics can be not very sensitive to particular experiences and specific economic situations within a country, because of the uniformity of contemporary mass media.

Considering the Multivariate Similarity Analysis ${ }^{1}$ of "daily changes, strategies, causes and solutions", we can figure out some elements of comparison between the Italian (Figure 1, 2, 3 and 4) and the Greek (Figures 5 , 6, 7 and 8) social representations of crisis contents.

Firstly, it is possible to observe that Greek similarity graphs do not show the same differences noticed looking over the Italian ones. In fact, the Italian multidimensional similarity graphs gave the idea of three different visions of crisis, a "theoretical-financial vision" for students and bank clerks, a "professional-oriented vision" for shopkeepers and a "practically/politically-oriented vision" for laypeople. Greek participants, on the contrary, seem to share the same "practically/politically-oriented vision". Despite this general difference between Italian and Greek similarity graphs, there are common elements organized in a different way. In particular, we can notice that the main Italian cluster of changes in daily life-"My relation with money has changed" (DC02), "I feel anxious and future anguishes me" (DC07), "I buy only less expensive and essential things" (DC08), "I've become more prudent, reflexive and I keep more informed" (DC01) - is also part of the Greek main clusters, but with a lower relevance of the last two components. These elements sometimes are in a more peripheral position, while another daily change "I can't do anymore what I used to do before: holidays, going out, restaurants" (DC05), absent in the Italian similarity graphs, is frequently associated in the most central Greek clusters. So, while Italian participants indicate that the limitation of buying and the occurred necessity of keeping informed is central in their way of thinking the crisis, Greek participants seem to signalize that they have already overcome this kind of daily changes, now being forced to give up a wide range of things.

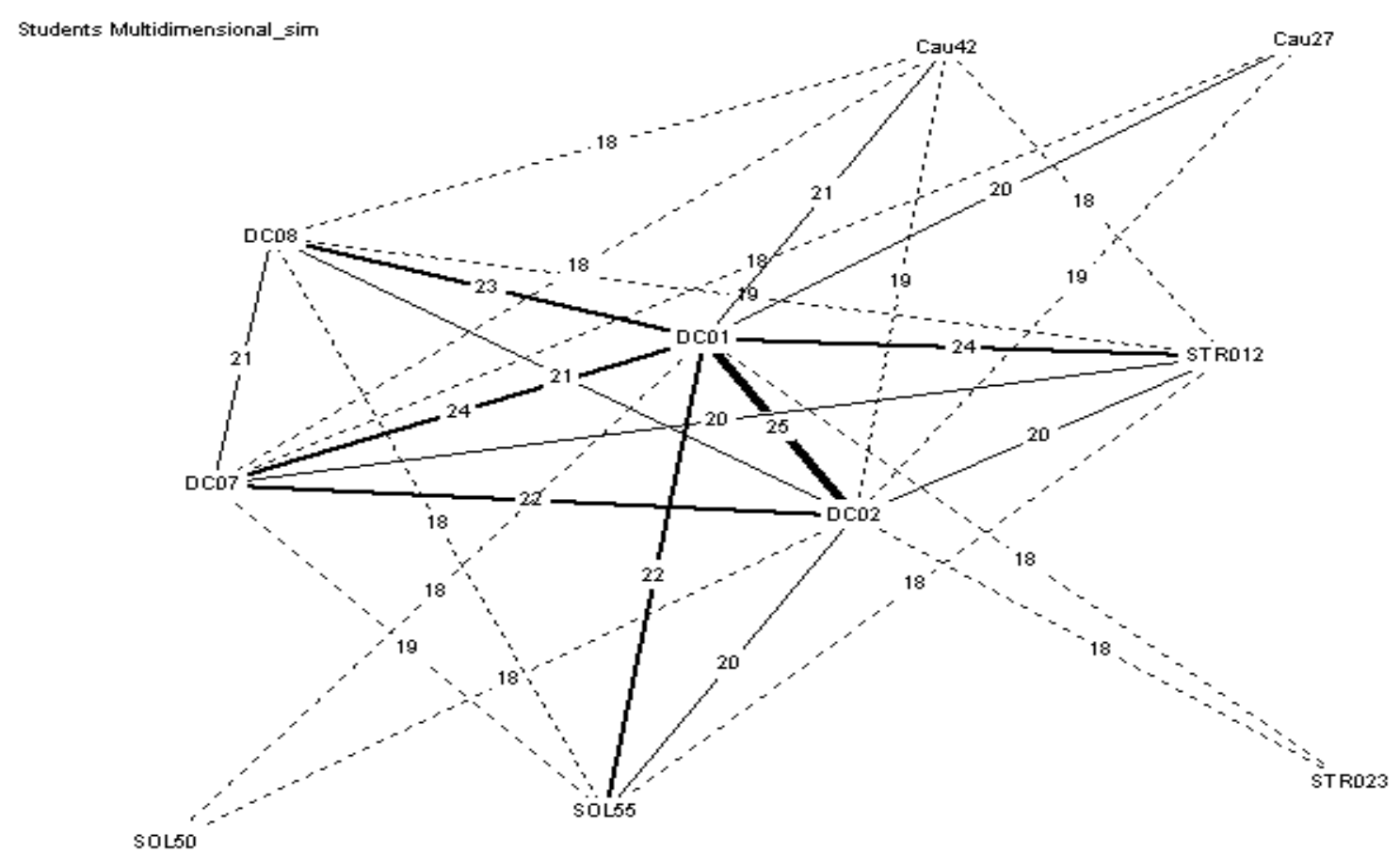

Figure 1. Italian students multidimensional similitude graph: daily life changes, causes, strategies and solutions. (Thresholds: 18). Co-occurrence criterion.

${ }^{1}$ Mainly for reasons of space, general Similarity Analysis outputs and discussion, are not provided in this paper. 


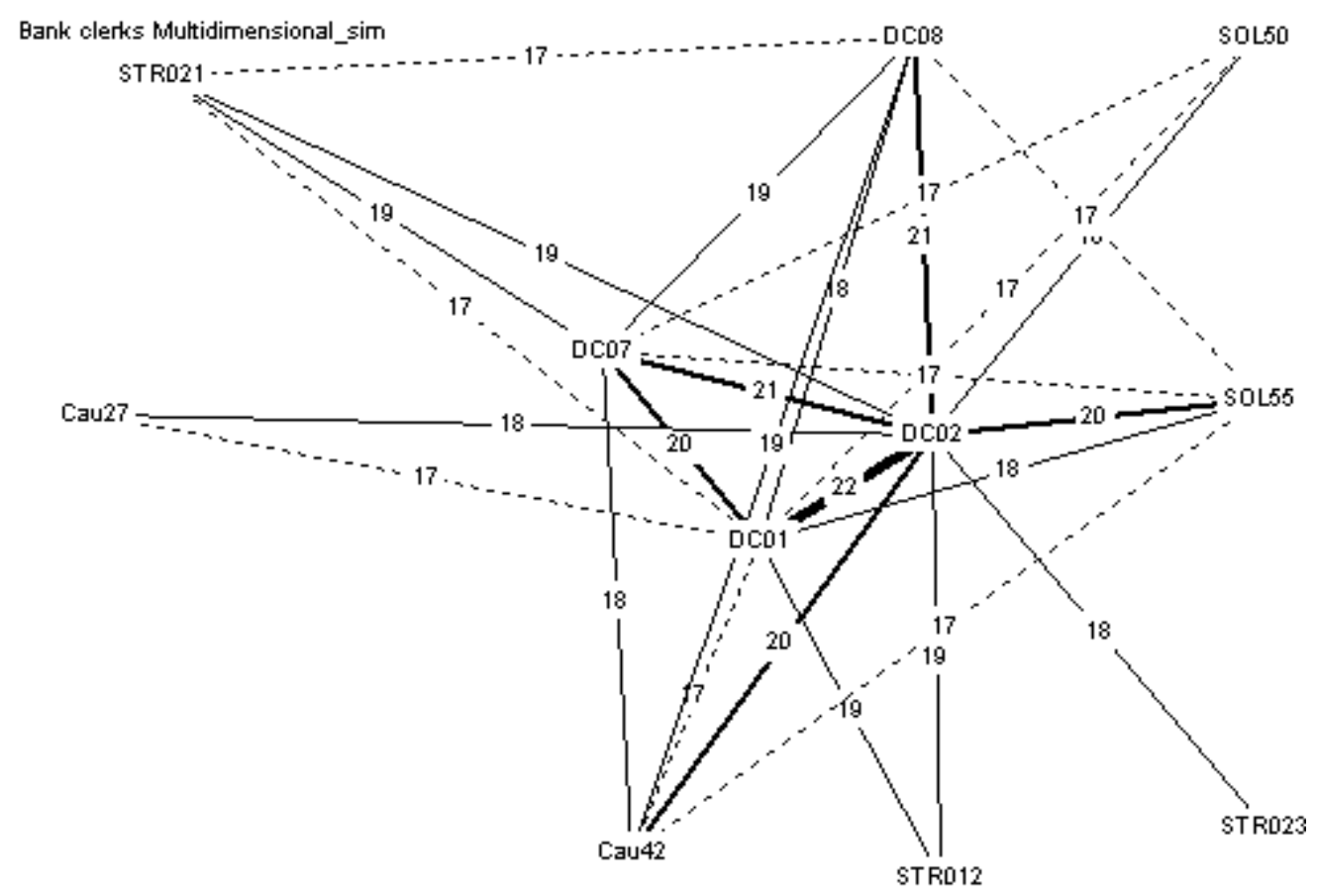

Figure 2. Italian bank clerks multidimensional similitude graph: daily life changes, causes, strategies and solutions. (Thresholds: 17). Co-occurrence criterion.

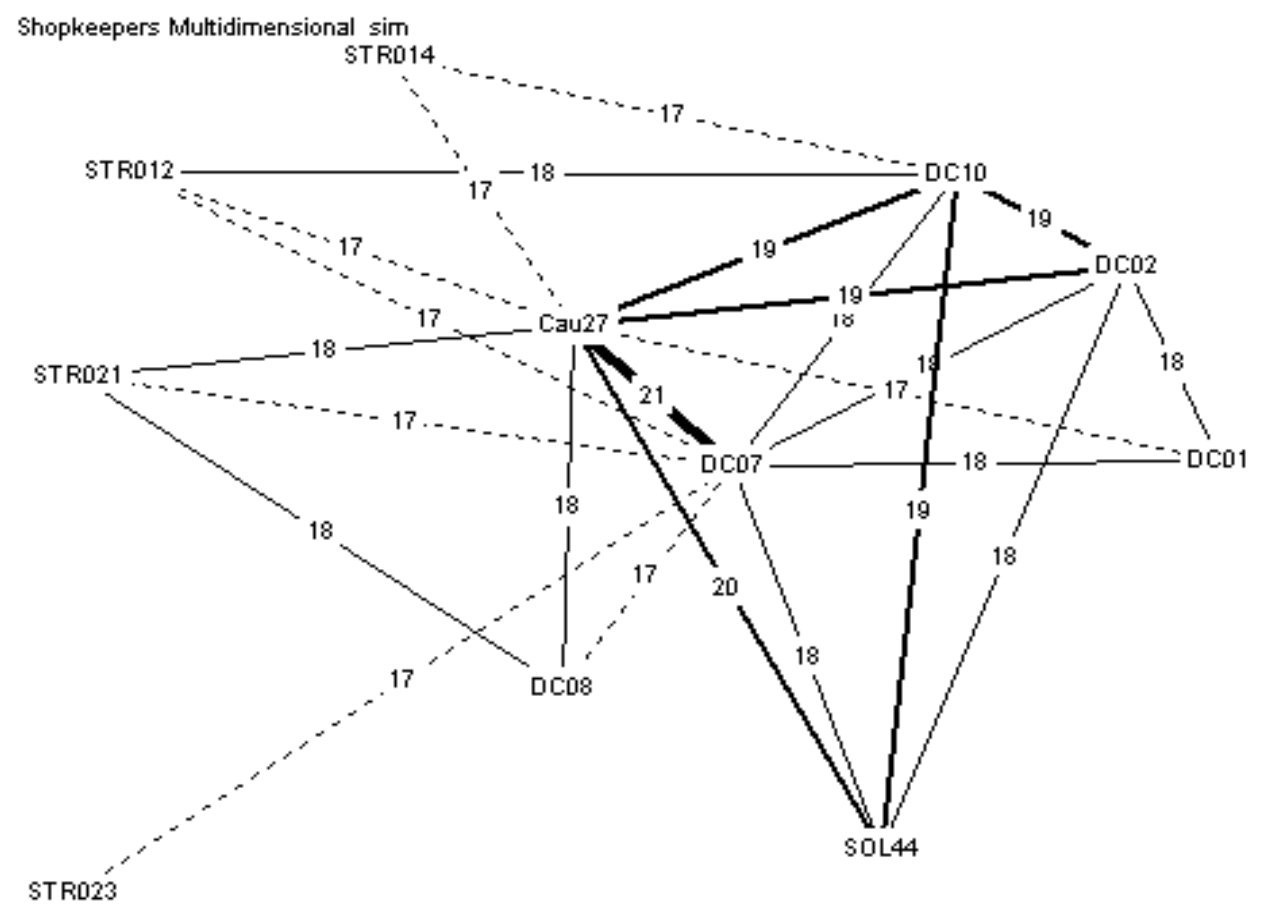

Figure 3. Italian shopkeepers multidimensional similitude graph: daily life changes, causes, strategies and solutions. (Thresholds: 17). Co-occurrence criterion. 


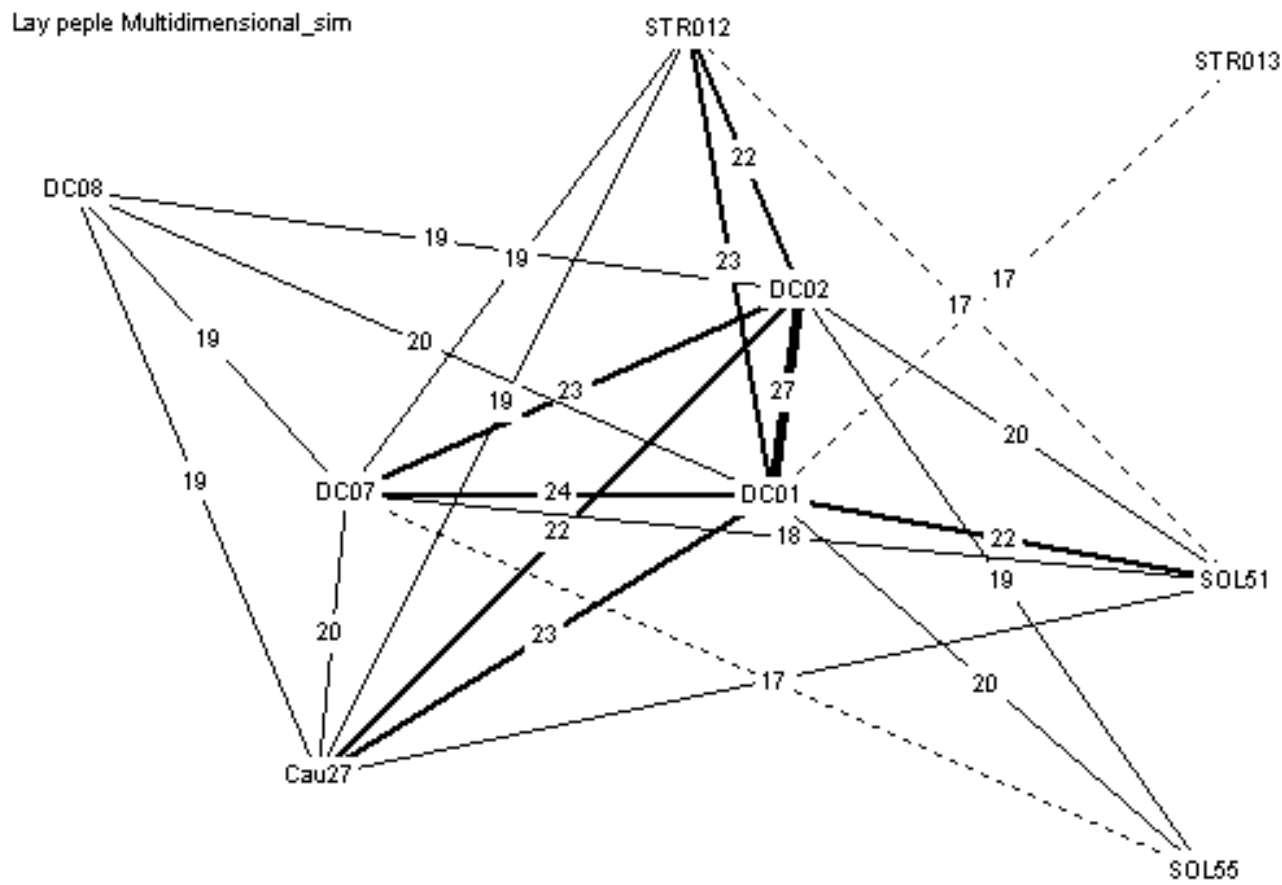

Figure 4. Italian laypeople multidimensional similitude graph: daily life changes, causes, strategies and solutions. (Thresholds: 17). Co-occurrence criterion.

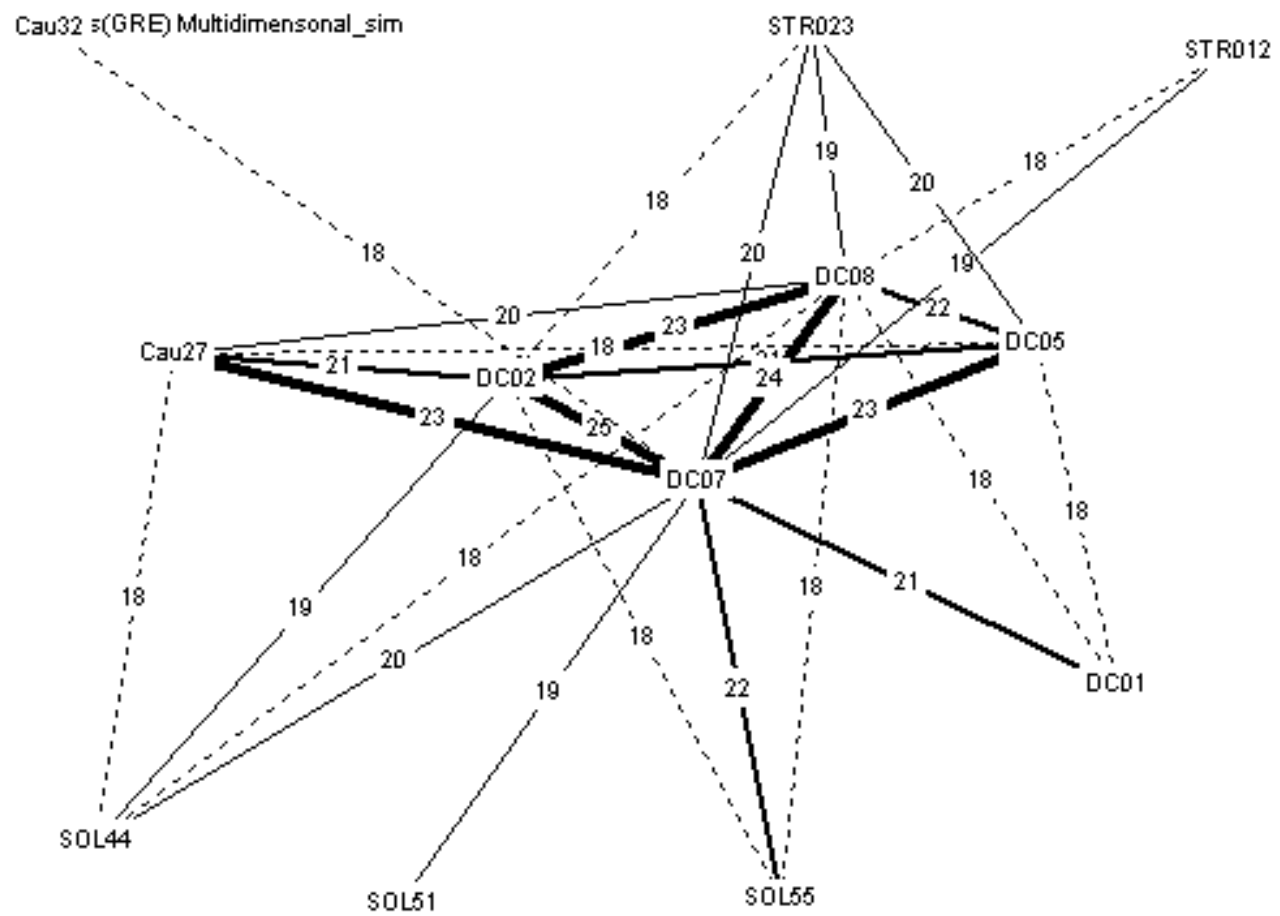

Figure 5. Greek students multidimensional similitude graph: daily life changes, causes, strategies and solutions (Thresholds: 18). Co-occurrence criterion. 


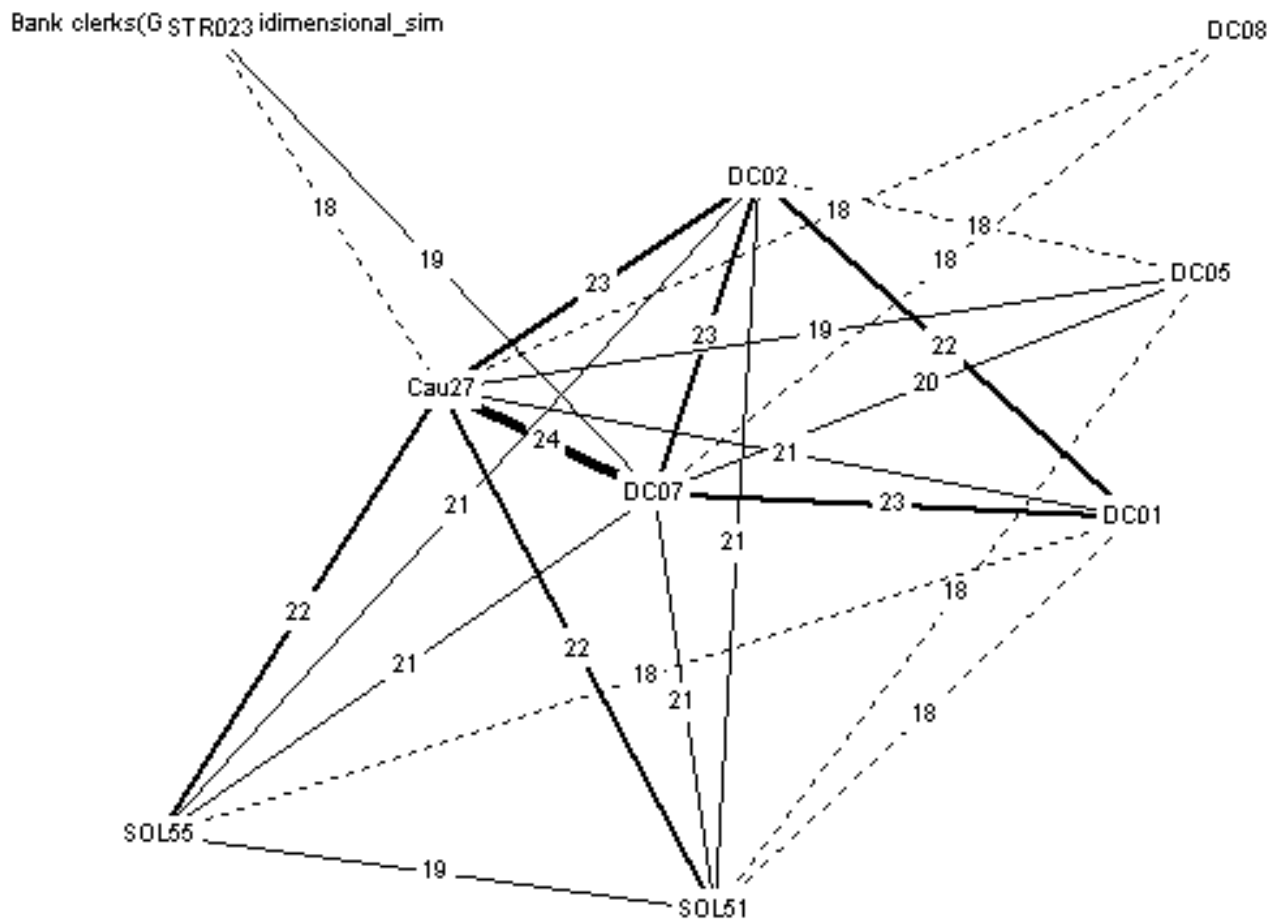

Figure 6. Greek bank clerks multidimensional similitude graph: daily life changes, causes, strategies and solutions (Thresholds: 18). Co-occurrence criterion.

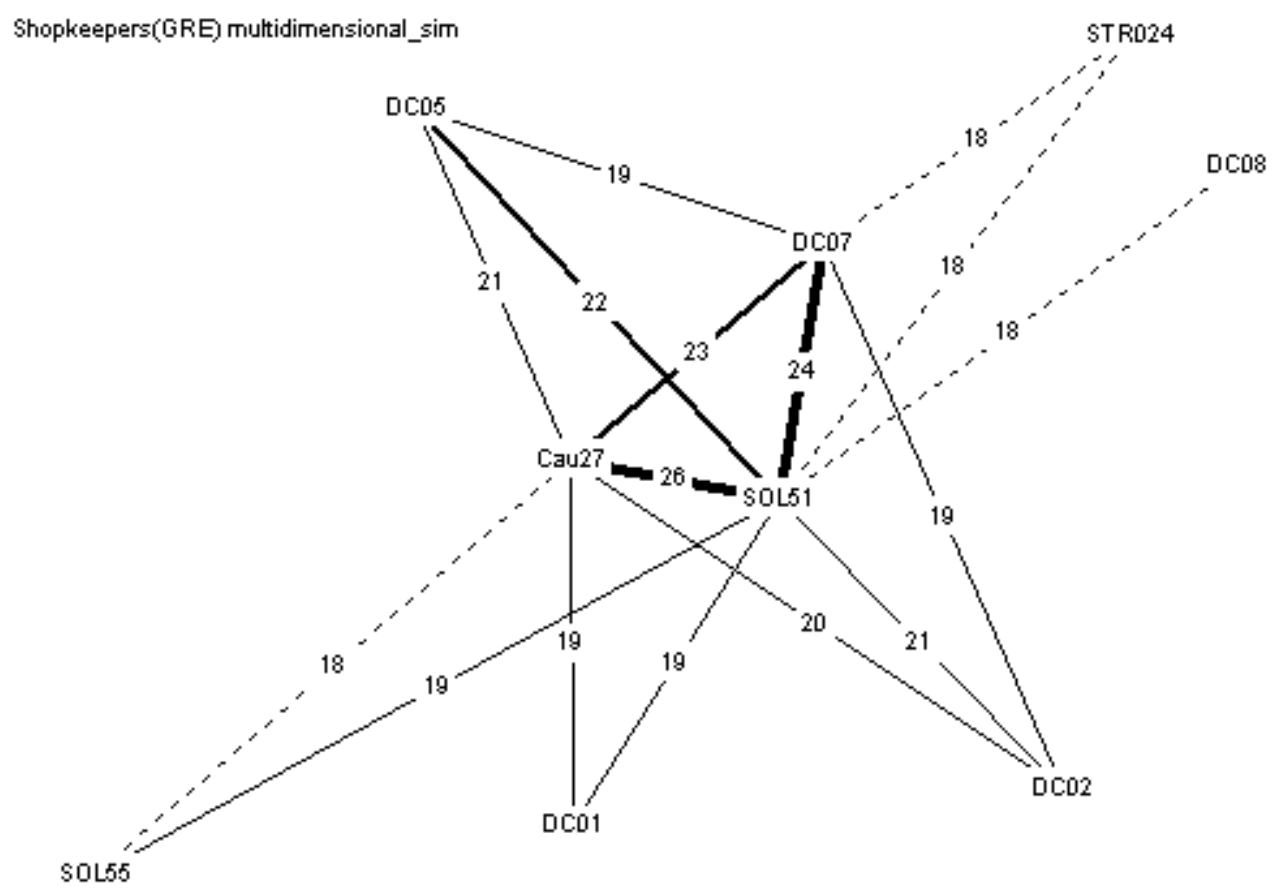

Figure 7. Greek shopkeepers multidimensional similitude graph: daily life changes, causes, strategies and solutions (Thresholds: 18). Co-occurrence criterion. 


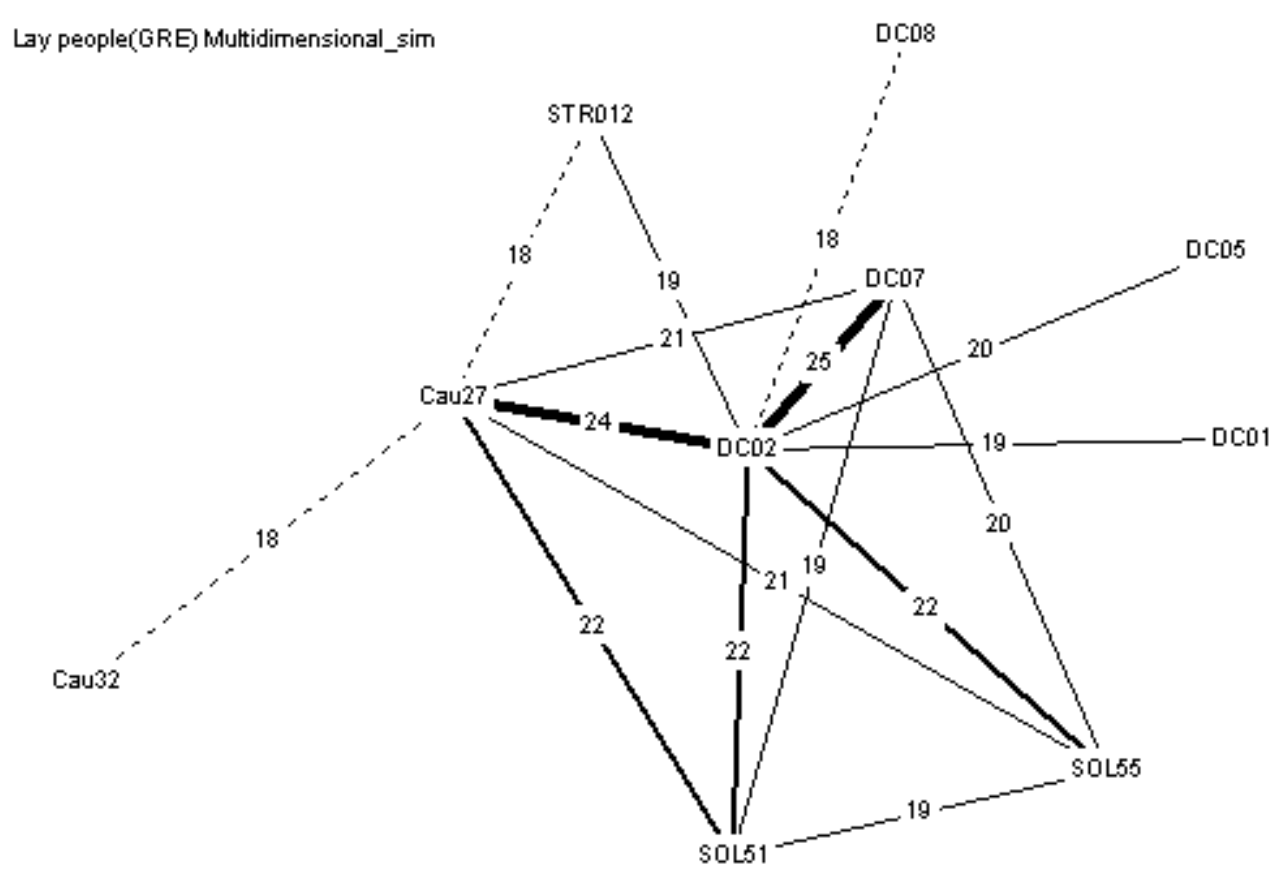

Figure 8. Greek laypeople multidimensional similitude graph: daily life changes, causes, strategies and solutions (Thresholds: 18). Co-occurrence criterion.

With reference to "Attributions", in all the Greek as well as Italian similarity graphs, the main associated cause is always "Corrupt, dishonest and unable to govern politicians" (CAU27). Nevertheless, while in Italian similarity graphs, this category is central only in the case of shopkeepers and laypeople graphs, in Greek ones it is part of the most central cluster for all the participants. The Greek explanations of crisis attribute a fundamental role to the incapacity of politics. Another cause frequently linked with other elements, in the Italian students and bank clerks similarity graphs, is "Financial speculation and the immediate profits desire" (CAU42). Otherwise, in Greek similarity graphs, there is a different cause of the crisis, "Uncontrolled loaning by banks" (CAU32), which is associate with the changed "Relation with money" (DC02) in students' graph and with the "Incapacity of politicians" (CAU27), in laypeople's one. This indicates that the secondary cause to which participants attribute crisis, "Financial speculation and immediate profits desire" (CAU42) for Italian students and bank clerks, and the "Uncontrolled lending by banks" (CAU32) for Greek students and laypeople, differentiate Italian from Greek participants.

As regards the ways of participants to face crisis, in comparison with the wide range of strategies that appear in Italian participants graphs, in Greek participants they are less numerous. The most chosen Italian strategy "I keep more informed about politics, economics and finance" (STR12), it's also frequent in Greek students and laypeople similarity graphs. Anyway, in Greek students graph, the most connected and important strategy is "I find alternative ways of having fun" (STR23). On the contrary, in Italian students graph, it is less frequently and strongly interrelated. With reference to bank clerks and shopkeepers, Greek participants similarity graphs present just one strategy each group. For Greek bank clerks, this strategy is "I find alternative ways of having fun" (STR23), more associated with the other elements than in Italian bank clerks graph, in which we found as relevant elements: "I keep more informed about politics, economics and finance" (STR12) 
and "I buy low quality brands products" (STR21). Greek shopkeepers' graph presents just one strategy, "I had to change my values priority order" (STR24), completely absent in the other Greek as well as Italian similarity graphs.

With regard to the solutions presented in the multidimensional similarity graphs, Italian and Greek participants (even if in different sub-samples) seem to think about the same way to solve the crisis. One of the most frequently and strongly associated solution is "Fight against tax evasion and proper management of taxation" (SOL55), which appears in both Italian and Greek similarity graph of students, bank clerks and laypeople. Shopkeepers are the group that seems to present always the most diversified configuration of elements. In the case of Greek students, the solution mentioned above appears together with "Election of more proper and capable politicians" (SOL51) and "Tax and imposts reduction" (SOL44). Italian students add to it (SOL55) "More equitable wealth distribution" (SOL50), an ideal solution shared also by Italian bank clerks, but completely absent among Greek participants, more oriented to practical solutions. In Greek bank clerks' similarity graph, in fact, it is central the "Election of more proper and capable politicians" (SOL51), that is highly associated also in all the other similarity networks, differently from Italian ones, where it appears just in the laypeople graph. This confirms a higher awareness, for Greek participants, of the responsibility of politics and politicians and the necessity to act directly on it to solve crisis. This kind of consciousness seems to be shared just by Italian laypeople participants. Similarly, also in the case of Greek shopkeepers, the only solution they propose is "Election of more proper and capable politicians" (SOL51), while the Italian shopkeepers prefer "Tax and imposts reduction" (SOL44).

The study confirms that "Job loss" remains undeniably a central and a stable part of the social representation of the economic crisis. However, in the particularly economic and political upsetting context of the Greek society, from 2009 to 2012, the social representation of the economic crisis evolves and changes. Firstly, we can see a rise of emotional elements, indicating either psychological distress (anxiety, insecurity, fear) or social distress (decency, misery). This is confirmed by QCha in 2012, which highlights the "Uncertainty and fear of the future" as a central element for all the involved groups. In addition, new elements related to control policies of the crisis are also emerging (IMF, euro, austerity, memorandum, salary reduction). On the other hand, the disappearance of elements referring to the crisis's financial/banking system is observed. From the beginning of the crisis, the financial/banking system was presented by the media as the most affected area; but for the Greek society it is just media information, without direct influence on their daily lives. However, as the crisis progressed in the time, it had a real impact on their income and lifestyle. It should be noted that between the two time campaigns, the Greeks have lost around $40 \%$ of their income and that the unemployment level of $10.3 \%$ in 2009 reached $21.5 \%$ in 2012. So, the crisis, a media event in 2009 turns to an experienced event in 2012. Yet it is interesting that the structure of SRsEC, in 2012 highlights the crisis as something unavoidable, an invention of media and a plot/conspiracy. Despite the considerable impact of the crisis in everyday life, we see that media, economic interests and the fatal nature of the crisis, seem well anchored in its representation.

Otherwise, the Multivariate Similarity Analysis of "daily changes, causes, strategies, and solutions" shows more consensus among the four groups than differences. This illustrates the impact of the crisis on all social strata. The crisis has drastically changed the economic practices of the Greeks. It has changed their relation with money, their habits, their consumerism, causing anxiety feelings about the future. Another element that marks a fair consensus between groups, for both, causes of and solutions to this crisis, is the fundamental role 
attributed to politics. Incompetence and immorality of political actors are seen as the main cause of the crisis, while the election of capable and morally integral political actors came to solution. Finally, the strategies chosen to confront the crisis reveal an individual and adaptive attitude. We attest that having fun, an important value of the decade of 2000's, linked in the Western world with the idea of consumption (Geka, 2003) remains an aspiration in Greek society despite the decrease in income. Other chosen strategies also show a link with values: Although the economy is a fundamental engine of life, it should be noted that it is never independent from values that organize our lives, our society. That is why an economic crisis is also a crisis of values.

\section{Conclusion}

"Job loss is the nightmare of our times". That's the mantra of every media, public, familiar discourse, expressly related or not to crisis, of our daily life. "Crisis does not exist" was the mantra at the beginning, before of the more and more serious slump of the economics and politics credibility in giving solutions to crisis, arriving to "Austerity is the answer" that haven't limited the general world recession and the terrible consequences for common people, being so ironically put into question by an "excel error" (Krugman, 2012).

In this scenario, the aim of this research was to explore this evolution towards the "naive theories" of different categories of people in the two different stages of the crisis $(2009,2012)$ and in different countries. How common, real people, with different kind of expertise about economics and politics, on the base of their daily professional and cultural environment, interpret and construct a coherent representation of such a complex phenomenon? Which are the differences in these social representations between the two moments of crisis?

Despite the intention of the media mantras, common people always create their own theories to understand a new, unfamiliar and threatening phenomenon, through the collective communication. Since 2009, in fact, it was clear, as evident in this research, that the financial explication of crisis, that politics tried to diffuse, was never completely accepted, but it was reworked in theories more pertinent to the reality this research participants lived in. Before the media discourse arrived to the conclusion that "Job loss is the nowadays nightmare", it was already the core of our participants social representations since 2009. Laypeople, as shown in other researches, also seem to focus on unemployment when they think about the crisis and differ in their notions of the crisis depending on whether they are afraid or unafraid of its consequences (Roland-Lévy, Pappalardo, Boumelki, \& Guillet, 2010). Nevertheless, in 2012, the most shared and important part of their representations anticipated again the forthcoming mantra: "Future is the nightmare of our century". As it appears from research participants 2012 central cores, "Uncertainty, fear of future", is the new, almost omnipresent element, which characterizes both Italian and Greek social representations. This "Uncertainty, fear of future" is not a "metaphysical fear", or something linked to the future perspective of the modern man. More implicitly or explicitly linked to "Job loss", it represents the putting into question of a configuration of hopes and certainties that obligatory involves an identity reconstruction. As also Hegel (trans. 2000) affirmed, the objective man is the result of his work. Losing it does not mean to lose just a way to gain money to survive, but it means to lose the way to place his identity in the world and the power to plan the future.

From our research results, since 2009, it was clear that there were some differences in the way of "differently expert" participants to construct their reasoning about the crisis. As already happened in Galli et al. (2010), in the different representational structures of the three "expert categories"-identified from their "distance from the object" - the same elements were used in explaining the crisis but with a different meaning. Moscovici $(1986 ; 1988)$ defines this kind of social representation "critical/polemical". The analysis of structure 
and content of the fourth involved social category, laypeople, brought to underline some unexpected differences. These "non-expert" people, beyond differentiating its central core with the reference to "Slump of purchasing power"- so to something more referred to the concrete consequences on everyday life-registered, already in 2009, a reference to "Uncertainty, fear of future": an element very salient and important for a minority of interviewees belonging to this category. This "anticipatory" element was the only one that seems to differentiate laypeople from the other categories. In fact, elements that suggest a laypeople utilization of abstract and theoretical elements, next to the references to more practical consequences, are not absent in constructing their naï theory, as shown by the "References to economy" and "Uncertainty, fear of future". Besides, the analysis of social representations of crisis' content does not suggest a real distinction between "expert" and "non-expert" knowledge, because the prevalent laypeople answers do not differ by all the other participants' ones. The social group that seems to differ the most in the way of thinking the crisis, since 2009, is the shopkeepers' one. Not only their central core but also the different components of the content seem to suggest a more professionally oriented optic, different from the more theoretical one of students and bank clerks, and the mixed one of laypeople.

In 2012, these differences between groups of participants seem to be accentuated. The particular vision of shopkeepers is confirmed by structure analysis as well as by SR's content analysis. In the structure analysis, referring to the central core, the biggest difference is that "Uncertainty, fear of future" is not central, while it is central "Increase of prices", strictly correlated to their activity. In addition, the significant differences in the SR's content analysis, supported by the details on every component through similarity graph, show the professionally oriented and absolutely different vision of shopkeepers. Therefore, with reference to our participants, professionalization appears not to be sufficient to mark a difference between "expert" and "non-expert" knowledge, but probably some kinds of professional contexts orientate stronger differences in constructing the social representation of such a complex economic phenomenon. Probably the "distance from the object" should be reinterpreted and modulated in a more qualitative way, according with the different "professional habitus".

The difference we could draw between the three expert categories and the non-expert one comes out from Similarity Analysis. What we can observe in characterization similarity graphs, as well as in the other content component graphs, is that while for the first three categories, it is possible to find particular visions of crisis, it is not possible in laypeople graphs. This could be referred to the different evolution that the expert/non-expert knowledge has had, arriving to a higher level of "schematization" for expert knowledge and resting on the phase of "connotation" for non-expert knowledge. The difference between expert and non-expert knowledge could influence more the degree of schematization of the social representation in the evolution process, rather than the differences between specific elements. Laypeople in fact seem to be not extraneous to abstract reasoning, more typical of students and bank clerks, but also to more practical and professional elements, so peculiar of shopkeepers. Anyway, when we analyze these elements together reconstructing the path of laypeople reasoning on crisis, the image we have is more focused on connotation of what crisis is not, despite what crisis is.

What we can conclude at this point of the research process is that there are certainly differences among social categories in both 2009 and 2012. These differences in 2009 are more relative to the sense given to the different elements, without huge differences between expert and non-expert knowledge, that oscillate between 
concrete and abstract reasoning. In 2012, the differences among categories of participants are accentuated in the direction identified in 2009, with the high differentiation of shopkeepers, relatively to the choice of different elements ("Increase of prices" and "Slump of consumption") and the way to put them together in the reasoning about crisis. This way, in particular, discriminating from more schematic and more connoted representations, marks a distinction between expert/non-expert knowledge, which seems to suggest an association between expertise and schematization of reasoning. The evolution in 2012 of the analysed SREC is testified by the appearing of new elements in the central core, generally the "Uncertainty for future", but also by an increase differentiation among social categories and between expert/non-expert people.

As regards a more specific comparison between Italian and Greek social representations of crisis, it is worth noticing that the main elements are in common, but some differences can be found in the meaning of some elements or in the particular use of them, as it happens in the case of "Austerity measures" and "Decadency". The Multidimensional Similarity Analysis shows how the vision of crisis is more schematized and differentiated for Italian than for Greek participants. For these interviewees, in particular, "Job loss" remains undeniably a central and a stable part of the representational object of the economic crisis. The study of representational content and organization of the four Greek groups involved, allow to identify two approaches to the crisis: an "emotional and fatalistic approach", shared particularly by lay people and shopkeepers, and a "theoretical and practical expert knowledge approach" mainly expressed by the students. These results confirm those of 2009. The group of shopkeepers was the most emotionally involved while the group of students was at least. The group of bank employees was as an intermediate group. These results allow us to conclude that, despite the change of words, the conceptual axes remain the same over time for the studied groups.

A methodological reflection can be done too. The use of QCha gave us the possibility to identify a central element, "Uncertainty, fear of future", which was not freely evoked by our participants. This information was extremely useful to better qualify the central core of our SRsEC's structures but at the same time to confirm their superposability.

Consequently, the integration of Hierarchized Evocations and QCha allows to highlight the centrality of elements that could be not spontaneously evoked as central and, at the same time, of elements not provided by the researcher.

The same remarks can be done for the used set of analysis. If similarity analysis is generally used to catch the associative value of central elements but in particular to have a major view on the connection that make the reasoning of people, it's also evident that the Multidimensional Similarity Analysis gives the additional opportunity of having a snapshot of the connections among different kinds of elements.

Moreover, the use of motivation in the questionnaire of evocation gave us the possibility to clearly understand the meaning of each associated term in the following cases: (1) when the term should suggest other meanings, as it happens for "dismissal, sons, young people", all expressed in the meaning of "Uncertainty, fear of future"; (2) in the case the evoked term seems to be completely unrelated to the inductor term, as it happens with "hang glider", used signifying "Uncertainty, fear of future", "to go into the infinite without destination/sure aim and with feet far from the ground" (BankIt_M19), or "tree", indicating "Necessity of change", "full of deadwood to cut" (BankIt_M19); (3) in case of a term used in a double meaning, as it happens for the "References to bank" in the students SREC 2012, used as cause "they are who provoked the crisis" (StudIt_F10) and effect "it failed" (StudIt_F2); (4) to understand the articulation of reasoning behind the 
evocation of a term as in the case of Germany "with its enormous public debt, it is going to make fall again the weight of crisis on Italy" (ShopIt_M24), or "getting into debt", "the high public debt oblige the State to an inactive public economic policy, because strangled by payment of interests at the expense of investments and takes reduction" (LayIt_M8); and (5) to specify the meaning of the term like "Decadency" among Greek participants, when the justification gives the possibility to link the term not to a general state of society, but to a specific part of it, "problems about the health and educational system" (ShopGR_M39).

Finally, as regards the limits and future developments of this research, it is possible to notice that the inter-categorical differences and especially the differences between expert and laypeople should be better qualified. A useful direction could be the one already identified of using functional/normative dimensions applied to the social representations of crisis (Ernst-Vintila, Delouvée, \& Rouquette, 2010). This direction could add more information also about the relation that always exists among social representations of different objects. Every social representation can't be thought as isolated, but it is very difficult to separate social representations of different objects. An idea could be to apply the two-dimensional model of Moliner (1995) in a qualitative way, taking into account the value that Vergès identified for the justifications used in the Hierarchized Evocation Method: "The justification given for every term allows us to better understand the relations that people use thinking about the inductor". In this light also an analysis of the evoked adjectives could be done: "The introduction of adjectives separated from nouns allows to obtain an explicit attribution of value about the elements evoked" (Vergès, personal communication, November 15, 2011).

In conclusion, as Jodelet (1996) affirms, the exercise that consists in using results of psycho-social researches, to lead to more incisive actions, must still be done and it can be realized by every reader. In this sense, this state of knowledge provided for the public is, first of all, an instrument of work to feed the still unfinished process of research and reflection of the society on itself and it is just in this way that social sciences can be useful.

\section{References}

Abric, J. C. (1994a). Pratiques sociales et représentations. Paris, Presses Universitaires de France.

Abric, J. C. (2003). La recherche du noyau central et de la zone muette des représentations sociales. In J. C. Abric (Ed.), Méthodes d'étude des représentations sociales (pp. 59-80). Ramonville Saint-Agne : Érès.

Abric, J. C., \& Vergès, P. (1994). Les représentations sociales de la banque. Etudes et recherches du Gifresh, 26.

Antonides, G., Farago, K., Ranyard, R., \& Tyszka, T. (1997). Perceptions of economic activities: A cross-country comparison. In G. Antonides, F. Van Raij, \& S. Maital (Eds.), Advances in economic psychology (pp. 39-60). Chichester: Wiley.

Bardin, L. (2003). L'analyse de contenu et de la forme de communications. In S. Moscovici, \& F. Buschini (Eds.), Les méthodes des sciences humaines (pp. 243-269). Paris: PUF.

Dehm, H., \& Muller-Peters, A. (2001). The impact of economic representations and national identity. In C. Roland-Lèvy, E. Kirchler, E. Penz, \& C. Gray (Eds.), Everyday representations of the economy (pp. 205-231). Wien: Universitatsverlag.

de Rosa, A. S. (1990). Per un approccio multi-metodo allo studio delle Rappresentazioni Sociali. Rassegna di Psicologia, 3 , 101-152.

de Rosa, A. S. (1994). From theory to meta-theory in S.R.: The lines of argument of a theoretical-methodological debate. Social Science Information, 33 (2), 273-304. Retrieved November 27, 2008, from http://www.europhd.eu/html/_onda02/07/PDF/10 th_lab_scientificmaterial/derosa/1994_theory_to_metatheory\%20.pdf

Ernst-Vintila, A., Delouvée, S., \& Rouquette, M. L. (2010). La crise financière de 2008: Menace collective ou défi individuel? Une analyse de la pensée sociale mobilisée en situation de crise. Les Cahiers de Psychologie Sociale Internationaux, 87(3), 515-542.

Fasanelli, R., Galli, I., \& Sommella, D. (2005). Professione caregiver: Studio delle relazioni tra pratiche assistenziali e rappresentazioni sociali della malattia di Alzheimer. Napoli: Liguori. 
Flament, C. (1962). L'analyse de similitude. Cahiers du Centre de Recherche Opérationnelle, 4, 63-97.

Flament, C. (1994a). Structure et dynamique des représentations sociales. In D. Jodelet (Ed.), Lesreprésentations sociales (pp. 204-219). Paris : Presses universitaires de France.

Galli, I. (Ed.). (2003). Le dimensioni psicosociali della povertà: Un'analisi cross-culturale. Napoli, Italia: Edizioni Scientifiche Italiane.

Galli, I. (2006). La teoria delle rappresentazioni sociali. Bologna: il Mulino.

Galli, I., Markova, I., Bouriche, B., Fasanelli, R., Geka, M., Iacob, L., \& Iacob, G. (2010). La représentation sociale de la crise économique dans quatre pays européens. Les Cahiers Internationaux de Psychologie Sociale, 87(3), 585-620.

Gangl, K., Kastlunger, B., Kirchler, E., \& Voracek, M. (2012). Confidence in the economy in times of crisis: Social representations of experts. The Journal of Socio-Economics, 41, 603-614.

Geka, M. (2003). Penser le rapport des jeunes à la politique: une étude de valeurs et de représentations sociales (Thèse de doctorat, Paris : EHESS).

Guimelli, C. (1989). Pratiques nouvelles et transformation sans rupture d'une représentation sociale: la représentation de la chasse et de la nature. In J. L. Beauvois, R. V. Joule, \& J. M. Monteil (Eds.), Perspectives cognitives et conduites sociales (Tome 2, pp. 117-138). Cousset: Del Val.

Guimelli, C. (Ed.) (1994). Structures et transformations des représentations sociales. Lausanne: Delachaux et Niestlé.

Hegel, F. (2000). La fenomenologia dello spirito (Vincenzo Cicero, trans.). Milano: Bompiani (Original work published in 1807).

Jodelet, D. (1984). Représentations sociales: Phénomènes, concept et théorie. In S. Moscovici (Ed.), Psychologie sociale. Paris: Presses Universitaires de France.

Jodelet, D. (1989). Les representations sociales. Paris: Presses Universitaires de France.

Jodelet, D. (1996). Les processus psycho-sociaux de l'exclusion. In S. Paugam (Ed.), L'exclusion l'état des savoirs. Paris: La Découverte.

Kirchler, E. (2007). The economic psychology of tax behaviour. New York: Cambridge University Press.

Krugman, P. (2012). Fuori da questa crisi, adesso! Milano: Garzanti

Legardez, A. (2004). L'utilisation de l'analyse des représentations sociales dans une perspective didactique: l'exemple de questions économiques. Revue des sciences de l'éducation, 30(3), 647-665. Retrieved December 6, 2010, from http://www.erudit.org/revue/rse/2004/v30/n3/012086ar.pdf

Mardellat, R. (1994). Pratique commerciales et représentations dans l'artisanat. In J. C. Abric (Ed.), Pratiques sociales representations (pp.145-178). Paris: PUF.

Meier, K., \& Kirchler, E. (1998). Social representations of Euro in Austria. Journal of Economic Psychology, 19, 755-774.

Mitchit, R. (1994a). Représentations sociales et prise de décision en situations professionnelles (Thèse de doctorat en psychologie, Université Paul Valéry, Montpellier).

Michit, R. (1994b). Représentations sociales, jugements et memorization: trois recherches experimentales. Papers on Social Representations, 3(2), 106-117.

Moliner, P. (1995). A two-dimensional model of social representations. European Journal of Social Psychology, 25, 27-40.

Moscovici, S. (1984a). The myth of the lonely paradigm: A rejoinder. Social Research, 51, 939-968.

Moscovici, S. (1984b). R. M. Farr, \& S. Moscovici (Eds.) (1984). Social representations. Cambridge, United Kigdom: Cambridge University Press.

Moscovici, S. (1986). Editoriale. Psicologia e Società, 1, 3-4.

Moscovici, S. (1988). Notes towards a description of social representations. European Journal of Social Psichology, 18, 211-250.

O'Connor, C. (2011). Using social representations theory to examine lay explanation of contemporary social crises: The case of Ireland's recession. Journal of Community and Applied Social Psychology, 22(6), 453-469.

Puaschunder, J. M., (2012). On the social representations of intergenerational equity. Retrieved December 4 from SSRN: $\mathrm{http}: / / \mathrm{ssrn} . \mathrm{com} / \mathrm{abstract}=2011359$ or http://dx.doi.org/10.2139/ssrn.2011359

Roland-Lévy, C., Pappalardo Boumelki, F. E., \& Guillet, E. (2010). Representation of the financial crisis: Effect on social representations of savings and credit. The Journal of Socio-Economics, 39, 142-149.

Tyszka, T. (2001). Perception of economic phenomena: Personal experience versus mass communication. In C. Roland-Lévy, E. Kirchler, E. Penz, \& C. Gray (Eds.), Everyday representations of the economy (pp. 171-181). Wien: Wuv|Universitatsverlag.

Vergès, P. (1992). L'Evocation de l'argent: une méthode pour la définition du noyau central d'une représentation. Bulletin de Psychologie, 45(405), 203-209. 
Vergès, P. (1994a). Les représentations sociales de l'économie: une forme de connaissance. In D. Jodelet (Ed.), Les représentations sociales (p. 387-405). Paris: Presses universitaires de France (1re éd. 1989).

Vergès, P. (1994b). Approche du noyau central: propriétés quantitatives et structurales. In C. Guimelli (dir.), Structures et transformations des représentations sociales (pp. 233-253). Lausanne: Delachaux et Niestlé.

Vergès, P. (1995). Représentations sociales partagées, périphériques, indifférentes, d'une minorité.

Vergès, P., Tyszka, T., \& Vergès, P. (1994). Representation of economics by French and Polish students. In T. Tyszka (Ed.), Cognitive representations of economics. Warszawa Instytut Psychologii, Polska Akademia Nauk.

Vergès, P., Albertini, J. M., \& Legardez, A. (1995). Mental representations of the economy: A key factor in economic progress, French report. Paris et Aix-en-Provence: CNRS.

Vergès, P., \& Bastounis, M. (2001). Towards the investigation of social representations of the economy: Research methods and techniques. In C. Roland-Lévy, E. Kirchler, E. Penz, \& C. Gray (Eds.), Everyday representations of the economy (pp. 19-48). Wien: WUV|Universitatsverlag.

Vergès, P., \& Bouriche, B. (2009). L'analyse des données par les graphes de similitude. Retrieved June 3, 2011, from $\mathrm{http} / / / \mathrm{www}$.scienceshumaines.com/methodes-quantitatives-pour-les-sciences-sociales_fr_15151.html

Zappalà, S. (2001). Social representations of economics across cultures. In C. Roland-Lévy, E. Kirchler, E. Penz, \& C. Gray (Eds.), Everyday representations of the economy (pp. 183-203). Wien: Wuv|Universitatsverlag. 